\title{
Analysis of Destination Image and Memorable Tourism Experience on Revisit Intention through Satisfaction of Tourist in Maimoon Place
}

\author{
Alya Indriani ${ }^{1}$, Endang Sulistya Rini ${ }^{2}$, Beby Karina F Sembiring ${ }^{3}$ \\ 1,2,3Faculty Economics and Business, University of Sumatera Utara, Medan, Indonesia.
}

Corresponding Author: Alya Indriani

\begin{abstract}
This study aims to analyze the destination image and memorable tourism experience on revisit intention through tourist satisfaction at Maimoon Palace. The type of research used in this research is associative research. The population in this study were tourists who visited the Maimoon Palace with the samples taken in this study were 135 respondents. Withdrawal of the number of sample sizes is done by non-probability sampling using purposive sampling method. The data used are primary data and secondary data obtained through a list of statements and documentation studies. The data analysis technique uses structural equation modeling (SEM) with the Smart PLS version 3.0 analysis tool. The results of the study directly show that destination image has a positive and significant effect on revisit intention, memorable tourism experience has a positive and significant effect on revisit intention, destination image has a negative and significant effect on revisit intention, memorable tourism experience has a positive and significant effect on revisit intention, and tourist satisfaction has a positive and significant effect on revisit intention. Then the results of tests carried out indirectly indicate that tourist satisfaction is not able to mediate the relationship between destination image and revisit intention, but tourist satisfaction is able to mediate the relationship between memorable tourism experience and revisit intention.
\end{abstract}

Keywords: Destination images, memorable tourism experience, tourist satisfaction and revisit intention

\section{INTRODUCTION}

Almost in all corners of the expanse of the Indonesian Archipelago, the tourism industry has now been built. Starting from Sabang to Merauke which covers 34 provinces, a number of tourist destinations have become destinations for foreign tourists. Since 2016 the government has set the tourism sector as one of the priority sectors to be developed.

There are several factors that influence tourist visits, namely push factors that are social-psychological or person specific motivation and pull factors that are destination specific attributes. With the driving factor, a person travels but it is not clear which region/country he is going to (Wibisono, 2013).

The driving factors for tourism can be predicted from the population of a country of origin for tourists, their per capita income, the length of leisure time they have related to the seasons in a country, advances in information and transportation technology, developing marketing systems, world security, social and politics, and other aspects of tourism. others related to physical and non-physical tourists (Wibisono, 2013). In making an offer, we must be able to explain what will be offered to tourists, what attractions can be enjoyed by tourists, what types of transportation can be used by tourists, what facilities are available at these attractions, and who can be contacted as intermediaries. purchase of tour packages. Revisit interest is considered as tourist 
loyalty which can be useful in predicting consumer behavior in the future.

The city of Medan as one of the big cities in Indonesia has become one of the centers of economic activity and social activities in the community. In addition to being the center of the economy and government, this city has a variety of diverse tours. Various tourist objects and diversity can be found in the city of Medan and its surroundings, such as the Deli Serdang district which surrounds the land of the Deli Sultanate.

Medan, formerly known as Tanah Deli, is the third largest city in Indonesia after Jakarta and Surabaya with a diversity of tribes, ethnicities, and cultures in it such as the Batak, Malay, Javanese, Chinese, and other ethnic groups. Medan city is crossed by several rivers and all of them empties into the Malacca Strait. The rivers are Sei Babura, Sei Belawan, Sei Deli, Sei Sulang Saling/Sri Kera, Sei Kambing, Sei Badra, and Sei Denai. Medan is a very important trade, industry and business city in Indonesia. The population of Medan City is 2,524,321 people with a population density of around 9,522 people $/ \mathrm{km} 2$ (BPS data 2020).

Various categories of tourism can be an option when visiting the city of Medan. Along with changes in lifestyles and people's economic capabilities that encourage them to spend part of their time on excursions, they are one of the growth factors for the tourism industry both on a local, regional, national and even international scale. The tourism industry players must also continue to adjust and follow market demand. According to the Medan City Tourism Office, tourist destinations that attract local and foreign tourists in Medan are Maimoon Palace, Grand Mosque, Tjong A Fie's House, Graha Maria Annai Velangkanni, Rahmat International Wildlife Museum \& Gallery, North Sumatra State Museum, and other tourist destinations. which is in the city of Medan. Maimoon Palace is one of the historical tourist destinations in Medan City that still exists and was built during the Deli Sultanate era when it reached its peak of glory under the leadership of Sultan Ma'moen Al-Rasyid Perkasa Alamsyah. Maimoon Palace is a tourist destination visited by local and foreign tourists.

Currently the image of the Maimoon Palace itself is still not good and the desire of tourists to return to visit is still low, even though the Maimoon Palace is one of the cultural heritages that must be developed in order to become the main tourist attraction in the city of Medan. However, it seems that people are still less interested in visiting and preserving these attractions. One of the reasons people are less interested in visiting Maimoon Palace is due to the lack of maximum information about the culture of the tourist attraction, cleanliness that is still relatively bad, environmental sustainability, building rejuvenation, and others. In addition, both the Maimoon Palace and the North Sumatra Provincial Tourism Office rarely carry out promotions to attract the attention of tourists, both those who have never visited and those who have visited again. If Maimoon Palace can be developed optimally, then Maimoon Palace will be an interesting tourist place to visit. The Maimoon Palace can cooperate with the North Sumatra Provincial Tourism Office in terms of planning and infrastructure development. This basic need creates competition between regions to develop into a unique region (Rini \& Sembiring, 2019).

\section{LITERATURE REVIEW \\ Interested to visit again}

The concept of revisiting interest was adopted from the repurchase intention theory proposed by Kotler \& Keller (2016). Consumer buying behavior is often initiated and influenced by many external stimuli, both in the form of marketing stimuli and stimuli from the environment. The stimulus is then processed in accordance with personal characteristics before a purchase decision is finally made. The personal characteristics of consumers used to process these stimuli are very complex and one of 
them is the motivation to buy. Usually, tourists will choose a tourism destination to be visited and then evaluate the destination which will have an impact on the intention to visit again in the future. A pleasant, positive, and memorable experience can usually affect visitor satisfaction and revisit intention (Mahdzar, 2018). The intention to revisit tourists is generally considered as the next process of satisfaction.

Tourists who make return visits tend to stay longer at a destination, participate more intensively in consumptive activities, are more satisfied, and spread positive word of mouth, thus requiring only much lower marketing costs than the first visit (Zhang et al., 2018). One of post-consumption behavior is a person's intention to return to a destination, so that it can be said as a tourist who revisits a destination.

\section{Tourist Satisfaction}

Tourist satisfaction is also identified as one of the important factors to influence the future tourist acquisition and intention to revisit (Choo et al. 2016) because if tourists feel dissatisfied it can result in adverse future behavioral intentions for the company. Tourist satisfaction is examined as a result of tourist image, value, and perceived quality so that it is unique for each individual (Khuong \& Phuong, 2017).

Tourist satisfaction can be measured by the emotional response that follows from the cognitive response to the service experience (Cong, 2016) or the difference between pre-trip expectations and post-trip experience (Chen \& Chen, 2010). In other words, tourists feel satisfied when the comparison of previous expectations and post-trip experiences produces a pleasant feeling and they will feel dissatisfied when the result is a feeling of displeasure (Chen \& Chen, 2010; Cong, 2016). Zeithaml et al. (2013) suggested that satisfaction is not only a much broader concept than just an assessment of service quality, but is also influenced by other factors such as customer perceptions of service quality, product quality, price, and by situational factors and customer personal factors.

\section{Destination Image}

Destination image is considering what makes a destination attractive to consumers. Destination image involves the development, distribution, and promotion of a destination brand (Pike et al., 2019). Destination image focuses on an individual's overall perception of a place (Chiu et al., 2016). In addition, the image of a destination can be defined as a set of impressions, ideas, expectations, and emotional thoughts about a place (Assaker \& Hallak, 2013; Iordanova, 2017). Destination image is considered an important influencing factor in various conceptual frameworks that explain the tourist decision-making process.

Destination image is considered as a set of complex mental impressions and total feelings that potential tourists have towards a product, place, or tourist destination (Farias et al., 2013). According to Foroudi et al. (2018) the main factor in building a tourist image is to build a tourist area with the characteristics of the area. The image of a destination can be a tourist's intention to make a visit in the future or can recommend it to others.

\section{Memorable Tourism Experience}

Tourism experience can be defined as an important impression for individuals who make tourist visits that are subjective, affective, and long-lasting (Fernandes and Cruz, 2016). If the tourism experience is not easily forgotten and continues to be remembered by the person for a long time, it can be stated that the person has obtained a memorable tourism experience during a visit to a tourist destination. Memorable tourism experience (MTE) is a rational factor that has an impact on future behavior as the need to improve customer experience affects the intention to revisit tourists (Kim et al., 2012). In addition, according to Zhang et al. (2018) memorable tourism experiences are experiences that are 
selectively built from tourist experiences and can be recalled after the trip.

According to Kim et al. (2012), the discussion of memory should be included in the study of travel experiences because tourist experiences tend to occur at certain times such as school holidays, so that it makes the tourism experience an experience that is stored in a long-term memory that will provide memories, feelings of pleasure, and will be reflected over and over again by the individual. Kim et al. (2012) stated that not all tourism experiences can be remembered and that selective memorable tourism experiences are built from tourism experiences based on individual experience assessments. Tourists have different experiences even if they visit or do the same thing in the same location, but their mood and personal feelings at any given moment influence their interpretation of the experience.

\section{MATERIALS \& METHODS}

This type of research is associative research. According to Sugiyono (2016) associative research is research that aims to determine the relationship between two or more variables. The variables connected in this study are the dependent variable, namely the interest in returning $(\mathrm{Y})$, the intervening variable, namely tourist satisfaction (Z), and the independent variable, namely the destination image variable (X1) and memorable tourism experience (X2). The population in this study are tourists who have been to Maimoon Palace. The sampling technique in this study is the sample taken with a nonprobability sample design, namely a sampling technique that does not provide equal opportunities or opportunities for each element or member of the population to be selected as a sample. The sampling method used purposive sampling, namely the technique of determining the sample based on certain considerations or criteria (Sugiyono, 2016). Hair et al. (2010) recommends a minimum sample size of 5 times the number of question/statement items contained in the questionnaire. The total statements in this study were 35 statements so that the sample size of the study was 35 x $5=175$ respondents. With criteria aged 17 years and over and domestic tourists who have been to Maimoon Palace. Data analysis in this study used PLS-SEM analysis.

\section{RESULT}

\section{Respondents' Descriptive Results}

The descriptive results of the respondents showed that the majority of respondents were female (68.6\%). This shows that female respondents are more dominant than male respondents. According to research conducted by The American Consumer, women travel more often than men.

In addition, the majority of respondents are 17-25 years old (60.6\%). This shows that tourists who visit Maimoon Palace are 17-25 years old, because millennials like to find the latest information.

The majority of respondents who visited Maimoon Palace were university students (58.9\%) and were or had completed high school education or strata-1 education. This shows that Maimoon Palace is most visited by students due to their more free time and their desire to gain knowledge that they do not know.

Many tourists who visit Maimoon Palace are tourists who come from North Sumatra. This is because the distance or access from several cities in North Sumatra to the Maimoon Palace is easy.

The majority of tourists who visited Maimoon Palace were once (69.7\%) and aimed at education (65.1\%). This is because the majority of those who visit Maimoon Palace are just looking for knowledge or wanting to know about the history of the Deli Sultanate.

\section{Data Analysis Results}

The following table presents the path coefficient values and P-Values values for 
Alya Indriani et.al. Analysis of destination image and memorable tourism experience on revisit intention through satisfaction of tourist in Maimoon Place.

testing the significance of the direct effect and indirect effect.

\begin{tabular}{|c|c|c|c|}
\hline & Original Sample (O) & P Values & Description \\
\hline Memorable Tourism Experience -> Revisit Intention & 0,532 & 0,000 & Accepted \\
\hline Memorable Tourism Experience -> Tourist Satisfaction & 0,993 & 0,000 & Accepted \\
\hline Tourist Satisfaction -> Revisit Intention & 0,204 & 0,006 & Accepted \\
\hline Destination Image -> Tourist Satisfaction -> Revisit Intention & $-0,036$ & 0,061 & Rejected \\
\hline
\end{tabular}

\section{DISCUSSION}

\section{The Influence of Destination Image on Revisit Intention}

Based on the results of hypothesis testing, it is shown that the destination image has a positive and significant effect on the revisit intention. This is evidenced by the path coefficient value of 0.220 with a significant value of $0.024<0.05$, meaning that the destination image has a positive and significant effect on revisit intention to Maimoon Palace. So that the results of this hypothesis test are accepted.

The results of this study indicate that there is a positive and significant relationship between destination image and tourist revisit intention to Maimoon Palace. This means that the better the destination image of Maimoon Palace, the interest in returning tourists to Maimoon Palace will increase, and vice versa, the worse the destination image of Maimoon Palace, the interest in revisiting will decrease. The results of this study are in accordance with the opinion of Nassar, et al. (2015) that the destination image is a representation of tourist areas or the perception of tourists when visiting tourist areas. If a person's perception of the tourism object is high, it will increase the interest in visiting the tourist again. The results of this research on Maimoon Palace are in accordance with research conducted by Junaedi and Harjanto (2020) and Garanti et al. (2019).

\section{The Effect of Memorable Tourism Experience on Revisit Intention}

Based on the results of the hypothesis test, it is shown that the memorable tourism experience has a positive and significant effect on revisit intention. This is evidenced by the path coefficient value of 0.532 with a significant value of $0.000<0.05$, meaning that the memorable tourism experience has a positive and significant effect on revisit intention tourists to Maimoon Palace. So that the results of this hypothesis test are accepted.

The results of this study indicate that there is a positive and significant relationship between memorable tourism experiences and revisit intention tourists to Maimoon Palace. This means that the more memorable the tourist experience when visiting the Maimoon Palace, the interest in returning tourists to the Maimoon Palace will increase, and vice versa the less tourists' impression when visiting the Maimoon Palace, the interest in revisiting will decrease. The results of this study are in accordance with the opinion of Kim et al. (2017) that memorable tourism experience is a tourist experience towards a tourist destination that is memorable and positively remembered after the event occurs or after the visit is over.

\section{The Effect of Destination Image on Tourist Satisfaction}

Based on the results of hypothesis testing, it is shown that destination image has a positive and significant effect on tourist satisfaction. However, the results obtained prove that the path coefficient value is -0.179 with a significant value of $0.031<0.05$, meaning that destination image has a negative and significant effect on tourist satisfaction to Maimoon Palace. So that the results of this hypothesis test are rejected. 
The results of this study indicate a negative and significant relationship between destination image and tourist satisfaction to Maimoon Palace. This means that the high destination image of Maimoon Palace has low tourist satisfaction and will have an impact on tourist interest to visit again. The results of this study are in accordance with the opinion of Pike et al. (2019) that destination image involves the development, distribution, and promotion of a destination brand.

\section{The Effect of Memorable Tourism Experience on Tourist Satisfaction}

Based on the results of the hypothesis test, it is shown that the memorable tourism experience has a positive and significant effect on tourist satisfaction. This is evidenced by the path coefficient value of 0.993 with a significant value of $0.000<0.05$, meaning that the memorable tourism experience has a positive and significant effect on tourist satisfaction to Maimoon Palace. So that the results of this hypothesis test are accepted.

The results of this study indicate that there is a positive and significant relationship between memorable tourism experiences and tourist satisfaction at Maimoon Palace. This means that when tourists feel memorable when visiting Maimoon Palace, tourists will feel satisfied with the Maimoon Palace tourist attraction. Vice versa, when tourists feel unimpressive when visiting Maimoon Palace, tourists will feel dissatisfied with the Maimoon Palace tourist attraction. The results of this study are in accordance with the opinion of Zhang et al. (2018) memorable tourism experiences are experiences that are selectively built from tourist experiences and can be remembered and recalled after a trip.

\section{The Influence of Tourist Satisfaction on Revisit Intention}

Based on the results of hypothesis testing, it is shown that tourist satisfaction has a positive and significant effect revisit intention. This is evidenced by the path coefficient value of 0.204 with a significant value of $0.006<0.05$, meaning that tourist satisfaction has a positive and significant effect on revisit intention Maimoon Palace again. So that the results of this hypothesis test are accepted.

The results of this study indicate that there is a positive and significant relationship between tourist satisfaction and revisit intention to Maimoon Palace. This means that when tourists are satisfied when visiting Maimoon Palace, tourists will be interested in revisiting Maimoon Palace. Vice versa, when tourists are not satisfied when visiting Maimoon Palace, tourists will not be interested in visiting Maimoon Palace again. The results of this study are in accordance with the opinion of Guntoro \& Hui (2013) that tourist satisfaction is an assessment of a place or destination based on what is expected. If one's abilities exceed expectations, tourists will be satisfied and happy. If one's perceived abilities are below expectations, tourists will feel let down.

\section{The Influence of Destination Image on Revisit Intention through Tourist Satisfaction}

Based on the results of hypothesis testing, it is shown that destination image has a positive and significant effect on revisit intention through tourist satisfaction. However, the results obtained prove that the path coefficient value is -0.036 with a significant value of $0.061>0.05$, meaning that tourist satisfaction is not able to mediate the relationship between destination image and revisit intention to Maimoon Palace. So that the results of this hypothesis test are rejected.

The results of this study indicate that there is a negative and insignificant relationship between destination image and revisit intention to Maimoon Palace through tourist satisfaction. The results of this study are in accordance with the opinion of Assaker \& Hallak, 2013; Iordanova (2017) a destination image is defined as a collection of impressions, ideas, expectations, and emotional thoughts about a place. In 
addition, in tourism, tourist satisfaction is one of the main sources of destination competitive advantage (Sun et al., 2013) which is an important factor for the success of destination marketing and promotion strategies, because of its influence on destination choice decisions, tourist spending, revisit intentions, and recommendations to others (Yoon and Uysal, 2005).

\section{The Effect of Memorable Tourism Experience on Revisit Intention through Tourist Satisfaction}

Based on the results of the hypothesis test, it is shown that the memorable tourism experience has a positive and significant effect on revisit intention through tourist satisfaction. This is evidenced by the path coefficient value of 0.202 with a significant value of 0.005 $<0.05$, meaning that tourist satisfaction is able to mediate the relationship between memorable tourism experience and revisit intention to Maimoon Palace. So that the results of this hypothesis test are accepted.

The results of this study indicate that there is a positive and significant relationship between memorable tourism experience and revisit intention through tourist satisfaction to Maimoon Palace. The results of this study are in accordance with the opinion of Kim et al. (2012), namely the discussion of memory must be included in the study of travel experiences because tourist experiences tend to occur at certain times such as school holidays, so that it makes the tourism experience an experience that is stored in a long-term memory that will provide memories, feelings of pleasure, and will be reflected over and over again by the individual.

\section{CONCLUSION}

Based on the results of the analysis that has been done, this research can be concluded as follows:

1. Destination image has a positive and significant effect on revisit intention tourists to Maimoon Palace.
2. Memorable tourism experience has a positive and significant effect on revisit intention tourists to Maimoon Palace.

3. Destination image has a negative and significant effect on tourist satisfaction to Maimoon Palace.

4. Memorable tourism experience has a positive and significant effect on tourist satisfaction to Maimoon Palace.

5. Tourist satisfaction has a positive and significant effect on revisit intention to Maimoon Palace.

6. Destination image has a negative and insignificant effect on revisit intention through tourist satisfaction to Maimoon Palace.

7. Memorable tourism experience has a positive and significant influence on revisit intention through tourist satisfaction to Maimoon Palace.

Acknowledgement: None

Conflict of Interest: None

\section{Source of Funding: None}

\section{REFERENCES}

1. Assaker, Guy dan Rob Hallak. 2013. Moderating Effect of Tourist's NoveltySeeking Tendencies on Destination Image, Visitor Satisfaction, and Shortand Long-Term Revisit Intention. Journal of Travel Research. XX (X), 1-14.

2. Chen, Ching-Fu dan Fu-Shian Chen. 2010. Experience Quality, Perceived Value, Satisfaction, and Behavioral Intentions for Heritage Tourists. Tourism Management, 31 (1), 29-35.

3. Chiu, Weisheng, Shiheng Zeng, dan Philip Shao-Tung Cheng. 2016. The Influence of Destination Image and Tourist Satisfaction on Tourist Loyalty: A Case Study of Chinese Tourists in Korea. International Journal of Culture. Tourism and Hospitality Research, 10 (2), 223-234.

4. Choo, Hyungsuk, Kwangho Ahn, dan James Petrick. 2016. An Integrateed Model of Festival Revisit Intentions: Theory of Planned Behavior and Festival Quality/Satisfaction. International Journal 
Alya Indriani et.al. Analysis of destination image and memorable tourism experience on revisit intention through satisfaction of tourist in Maimoon Place.

of Contemporary Hospitality
Management.

5. Cong, Le Chi. 2016. A Formative Model of the Relationship between Destination Quality, Tourist Satisfaction and Intentional Loyalty: An Empirical Test in Vietnam. Journal of Hospitality and Tourism Management, 26, 50-62.

6. Farias, Salomão Alencar de Farias, Edvan Cruz Aguiar, Michelle Helena Kovacs, dan Francisco Vicente Sales Melo. 2013. Destination Image on the Web: Evaluation of Pernambuco's Official Tourism Destination Websites. Business Management Dynamics, 2 (10), 35-48.

7. Fernandes, Teresa dan Mariana Cruz. 2016. Dimensions and Outccomes of Experience Quality in Tourism: The Case of Port Wine Cellars. Journal of Retailing and Consumer Services. 31, 371-379.

8. Garanthi, Zanete, Shiva Ilkhanizadeh, dan Philip Siaw Kissi. 2019. The Impact of Branding on Tourist's Satisfaction and Loyalty in Iran. Bridging Tourism Theory and Practce, 10, 223-241.

9. Guntoro, Budi dan Tak-Kee Hui. 2013. Travel Satisfaction and Revisit Intention of Chinese Visitors: The Case of Singapore. 2013. Hospitality and Leisure, 9, 29-47.

10. Hair, Joseph F., William C. Black, Barry J. Babin, dan Rolph E. Anderson. 2010. Multivariate Data Analysis: Global Edition, $7^{\text {th }}$ Edition. New Jersey: Pearson Education.

11. Iordanova, Elitza. 2017. Tourism Destination Image as an Antecedent of Destination Loyalty: The Case of Linz, Austria. European Journal of Tourism Research. 214-232.

12. Junaedi, Sheellyana dan Jason Harjanto. 2020. Examining the Effect of Destination Awareness, Destination Image, Tourist Motivation, and Word of Mouth on Tourists' Intention to Revisit. International Symposia in Economic Theory and Econometics, 27, 27-38.

13. Khuong, Mai Ngoc dan Nguyen Thanh Phuong. 2017. The Effects of Destination Image, Perceived Value, and Service Quality on Tourist Satisfaction and WordOf-Mouth - A Study in Ho Chi Minh
City, Vietnam. International Journal of Trade, Economics and Finance, 8 (5). 217-224.

14. Kim, Jong-Hyeong, J. R. Brent Ritchie, dan Bryan McCormick. 2012. Development of a Scale to Measure Memorable Tourism Experience. Journal of Travel Research. Journal of Travel Research, 51 (1), 12-25.

15. Kotler, Philip dan Gary Armstrong. 2018. Principles of Marketing: Global Edition, $17^{\text {th }}$ Edition. England: Pearson Education Limited.

16. Kotler, Philip dan Kevin Lane Keller. 2016. Marketing Management. England: Pearson Education Limited.

17. Mahdzar, Mazlina. 2019. Tourist's Perception on Memorable Tourism Experience towards Their Revisit Intentions to Islamic Tourism Destination in Shah Alam, Selangor. Journal of Emerging Economies and Islamic Research, 7 (1), 37-44.

18. Nassar, Mohamed A., Mohamed M. Mostafa dan Yvette Reisinger. 2015. Factors Influencing Travel to Islamic Destinations: An Empirical Analysis of Kuwaiti Nationals. International Journal of Culture, Tourism, and Hospitality Research, 9 (1), 36-53.

19. Pike, Steven, H. S. Jin, dan Filareti Kotsi. 2019. There is Nothing So Practical as Good Theory for Tracking Destination Image over Time. Journal of Destination Marketing \& Management, 14.

20. Rini, Endang Sulistya dan Beby Karina F. Sembiring. 2019. Servicescape and Satisfaction as Antecedent of Revisiting Intention to Tourist Destination of Lake Toba. Revista de Ciencias Humanas y Sociales. 2899-2921.

21. Sugiyono. 2016. Metode Penelitian Kuantitatif, Kualitatif, dan R\&D. Bandung. Alfabeta.

22. Sun, Xiaoxia, Christina, Geng-Qing, dan Chi Honggang Xu. 2013. Developing Destination Loyalty: The Case of Hainan Island. Annals of Tourism Research, 43, 545-577.

23. Wibisono, Jeffrey V. 2013. Motivasi Berwisata dan Faktor Penariknya. Online.. 
Alya Indriani et.al. Analysis of destination image and memorable tourism experience on revisit intention through satisfaction of tourist in Maimoon Place.

24. Yoon, Yooshik dan Muzaffer Uysal. 2005. An Examination of the Effects of Motivation and Satisfaction on Destination Loyalty: A Structural Model. Tourism Management, 26, 45-56.

25. Zeithaml, Valarie A., Mary Jo Bitner, dan Dwayne D. Gremler. 2013. Services Marketing: Integrating Customer Focus across the Firm $6^{\text {th }}$ ed. Boston: Mc. Graw Hill.

26. Zhang, Hongmei, Yan Wu, dan Dimitrios Buhalis. 2018. A Model of Perceived Image, Memorable Tourism Experience, and Revisit Intention. Journal of Destination Marketing \& Management.
27. Zhang, Yunene, Wei Shao, dan Park Thaichon. 2021. Investigating Tourist Post-Travel Evaluation and Behavioral Intention: A Cultural Intelligence Perspective. Asia Pacific Journal of Marketing and Logistics

How to cite this article: Alya Indriani, Endang Sulistya Rini, Beby Karina F Sembiring. Analysis of destination image and memorable tourism experience on revisit intention through satisfaction of tourist in Maimoon Place. International Journal of Research and Review. 2021; 8(12): 597-605. DOI: https://doi.org/10.52403/ijrr.20211272 